\title{
THE EFFECT OF 2-DEOXY-D-GLUCOSE INFUSIONS ON LIPID AND CARBOHYDRATE METABOLISM IN MAN *
}

\author{
By JOHN LASZLO, WILLIAM R. HARLAN, ROBERT F. KLEIN, NORMAN \\ KIRSHNER, E. HARVEY ESTES, JR. AND MORTON D. BOGDONOFF
}

(From the Departments of Medicine and Biochemistry, Duke University Medical Center and Durham Veterans Administration Hospital, Durham, N. C.)

(Submitted for publication May 2, 1960 ; accepted September 15, 1960)

At the present time, the direction of change of the plasma free fatty acid (FFA) level is considered to serve as an index to the pattern of fat metabolism, representing an indicator of the balance between fat storage and fat mobilization. In the fasting, nonexercising individual, a rising plasma FFA level suggests net fat mobilization and a falling FFA level suggests net fat storage. If the status of carbohydrate metabolism does relate to fat metabolism, then plasma FFA levels may be expected to change in a number of experimental situations. Dole was the first to demonstrate that glucose and insulin administration decreased fasting FFA levels (1) and Bierman, Dole and Roberts that patients with diabetes mellitus have high FFA levels (2). Experimental inteference with carbohydrate metabolism might also be expected to influence plasma FFA levels. The availability of 2-deoxy-D-glucose (2-DG) has made it possible to test this hypothesis. 2-DG is phosphorylated to 2-deoxyglucose-6-phosphate (2-DG-6-P), and it has been postulated that the 2-DG-6-P may compete for transport into the cell with glucose-6-phosphate (3). The purpose of this study was to observe the effect of 2-DG administration on FFA levels in normal human subjects and to study in addition the effect of glucose, insulin, fructose and lactate upon the pattern of response to 2-DG.

\section{MATERIALS AND METHODS}

2-DG was purchased in the chemically pure form from the Nutritional Biochemicals Corporation. The compound was dissolved in distilled water, passed through a Seitz filter, and stored in a sterile container for intravenous administration. Aliquot samples were tested for bacterial contamination. 2-DG was prepared in 20 per cent

* Supported in part by the Duke University Center for the Study of Aging, Public Health Service Grants (M-2109) and (H-3582), in part by the Irwin Strasburger Memorial Medical Research Fund, and in part by the North Carolina Heart Association. solution and stored in the cold. For intravenous administration the final volume was made up to $100 \mathrm{ml}$ with normal saline.

Plasma glucose was measured by the Nelson modification of the Somogyi method (4), which also determines blood 2-DG levels. 2-DG levels were not specifically determined in these experiments but have been previously reported following the administration of a comparable amount of compound to humans. The 2-DG plasma levels rarely exceed $10 \mathrm{mg}$ per $100 \mathrm{ml}$ (5). FFA was measured by the method of Dole (1) as modified by Trout, Estes and Friedberg (6). Plasma lactate was measured by the Barker-Summerson method (7). Urinary epinephrine and norepinephrine levels were measured by the bioassay technique of von Euler (8).

Eleven subjects were selected for these studies on the basis of normal body build and no evidence of metabolic or endocrine abnormality. The subjects were either medical students or hospital patients with minor illnesses. All subjects were studied in the morning after a 12 hour overnight fast. On entering the laboratory, they were placed in bed and remained recumbent and quiet for the duration of the study. Needles were placed in a vein of each arm, one for the intravenous infusion of 2-DG, the other for sampling. Each sample consisted of $10 \mathrm{ml}$ of blood drawn into heparinized syringes and immediately placed on ice prior to centrifugation in the cold. Two or three pre-infusion samples were drawn starting at 10 minutes after placement of the needles. The 2-DG was infused at a constant rate over a 30 minute period. The total dose was $60 \mathrm{mg}$ per $\mathrm{kg}$ in all but two studies (one with $50 \mathrm{mg}$ per $\mathrm{kg}$ and one with $70 \mathrm{mg}$ per $\mathrm{kg}$ ). Blood samples were then drawn at 5 to 15 -minute intervals during the first hour of the experiment and at 30-minute intervals after that period. The experiments lasted approximately 3 to 4 hours. Signs and symptoms of drug effect were recorded in each instance. These included sweating, somnolence, hunger, and occasionally, nausea and restlessness. In no instance were the symptoms sufficiently disturbing to the subject to warrant discontinuing the study.

In the studies of sodium lactate, this compound was infused intravenously at various dose levels before, during or after the attainment of a clinical 2-DG effect. In other experiments, 25 or $50 \mathrm{~g}$ of glucose and $22 \mathrm{~g}$ of fructose were given intravenously after a 2-DG effect was apparent. Hyperglycemic-free insulin (HGF) was also studied in doses up to $8 \mathrm{U}$, administered intravenously 
in 2 to 3 minutes, and also after a 2-DG effect had occurred.

\section{RESULTS}

Figure 1 depicts a representative response to the infusion of 2-DG. The increase in plasma FFA began shortly after the start of the infusion, rose rapidly to a peak, and gradually fell toward the control levels over a 4 hour period. Plasma glucose levels first began to rise concurrently with the initial rise in FFA level but were more gradual in reaching a peak. Part of the immediate initial rise may be contributed by the 2-DG itself. In only one subject did plasma glucose fall toward pre-infusion levels within the 3 hour period of study. Blood lactate levels also rose gradually over a period of hours. Table I summarizes the nine experiments of unmodified 2-DG administration to normal subjects. It can be noted that irrespective of the pre-infusion FFA level, the response to 2-DG administration was invariably a

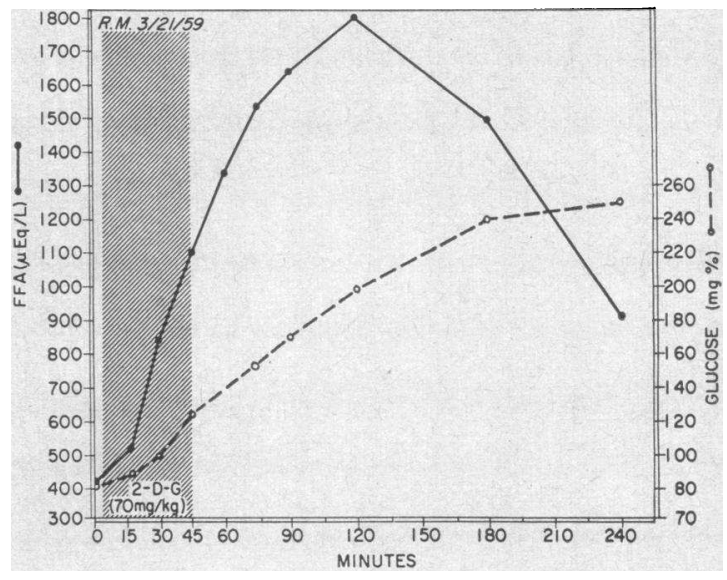

Fig. 1. A Representative pattern of response of PLASMA FREE FATTY ACID AND GLUCOSE LEVELS FOLLOWING AN INFUSION OF 2-DEOXY-D-GLUCOSE.

rise ranging from 1.5 (Subject C.C.) to 10 times (Subject J.S.) the pre-infusion level. There was overlap of only one control (C.C.) and one maxi-

TABLE I

Plasma free fatty acid, glucose and lactate levels before and after intravenous infusion of 2-deoxy-D-glucose (2-DG)

\begin{tabular}{|c|c|c|c|c|c|c|c|c|c|c|c|c|}
\hline \multirow[b]{2}{*}{ Subject } & \multirow[b]{2}{*}{ Control } & \multicolumn{10}{|c|}{ Minutes after completion of infusion } & \\
\hline & & $5-10$ & $15-20$ & 30 & 45 & 60 & 90 & 120 & 150 & 180 & 210 & \\
\hline \multicolumn{13}{|c|}{ Free fatty acid $(\mu \mathrm{Eq} / \mathrm{L})$} \\
\hline $\begin{array}{l}\text { 1. G.S. } \\
\text { 2. J.V. } \\
\text { 3. R.M. } \\
\text { 4. C.C. } \\
\text { 5. M.A. } \\
\text { 6. L.G. } \\
\text { 7. R.D. } \\
\text { 8. R.Me. } \\
\text { 9. J.S. }\end{array}$ & $\begin{array}{r}587 \\
324 \\
416 \\
846 \\
442 \\
893 \\
539 \\
356 \\
82\end{array}$ & $\begin{array}{r}910 \\
644 \\
1,100 \\
\\
1,046 \\
1,841 \\
1,209 \\
425\end{array}$ & $\begin{array}{r}1,402 \\
1,039 \\
1,332 \\
1,295 \\
\\
\\
1,812 \\
796 \\
485\end{array}$ & $\begin{array}{r}1,591 \\
1,279 \\
1,532 \\
1,257 \\
1,221 \\
2,200 \\
2,091 \\
\\
649\end{array}$ & $\begin{array}{r}1,424 \\
1,267 \\
1,638 \\
\\
954 \\
2,387 \\
1,810 \\
767 \\
769\end{array}$ & $\begin{array}{r}1,059 \\
\\
1,193 \\
948 \\
2,396 \\
\\
875 \\
822\end{array}$ & $\begin{array}{r}1,024 \\
1,178 \\
1,798 \\
1,116 \\
1,024 \\
2,299 \\
1,601 \\
719 \\
731\end{array}$ & $\begin{array}{r}1,156 \\
1,094 \\
1,494 \\
\\
856 \\
2,305 \\
1,125 \\
748\end{array}$ & $\begin{array}{l}1,202 \\
1,025 \\
1,168 \\
2,016\end{array}$ & $\begin{array}{r}998 \\
1,016 \\
914\end{array}$ & $\begin{array}{l}1,011 \\
1,048\end{array}$ & \\
\hline \multicolumn{12}{|c|}{ Glucose $(\mathrm{mg} / 100 \mathrm{ml})$} & $\begin{array}{c}\text { Glucose } \\
\text { release } \\
\text { rate } \\
\text { (g/hr) }\end{array}$ \\
\hline $\begin{array}{l}\text { 1. G.S. } \\
\text { 3. R.M. } \\
\text { 4. C.C. } \\
\text { 5. M.A. } \\
\text { 6. L.G. } \\
\text { 7. R.D. } \\
\text { 8. R.Me. } \\
\text { 9. J.S. }\end{array}$ & $\begin{array}{r}90 \\
83 \\
119 \\
87 \\
101 \\
89 \\
95 \\
85\end{array}$ & $\begin{array}{l}107 \\
124 \\
105 \\
131 \\
121 \\
109\end{array}$ & $\begin{array}{l}116 \\
133\end{array}$ & $\begin{array}{l}124 \\
156 \\
142 \\
121 \\
156 \\
189 \\
\\
135\end{array}$ & $\begin{array}{l}142 \\
170 \\
\\
143 \\
165 \\
215 \\
154 \\
151\end{array}$ & $\begin{array}{l}151 \\
\\
154 \\
154 \\
194 \\
\\
160 \\
158\end{array}$ & $\begin{array}{l}146 \\
198 \\
154 \\
165 \\
219 \\
233 \\
170 \\
183\end{array}$ & $\begin{array}{l}148 \\
240 \\
\\
180 \\
233 \\
233 \\
\\
189\end{array}$ & $\begin{array}{l}132 \\
161\end{array}$ & $\begin{array}{l}120 \\
250\end{array}$ & \multicolumn{2}{|c|}{$\begin{array}{r}27.6 \\
26.7 \\
8.7 \\
24.0 \\
51.6 \\
91.8 \\
51.9 \\
39.0 \\
\text { Mean } \\
40.2\end{array}$} \\
\hline \multicolumn{13}{|c|}{ Lactate $(\mathrm{mg} / 100 \mathrm{ml})$} \\
\hline $\begin{array}{l}\text { 3. R.M. } \\
\text { 4. C.C. } \\
\text { 5. M.A. } \\
\text { 10. H.J. } \\
\text { 11. A.N.* }\end{array}$ & $\begin{array}{r}7 \\
14 \\
12 \\
10 \\
11\end{array}$ & $\begin{array}{r}7 \\
12\end{array}$ & $\begin{array}{r}15 \\
9 \\
18\end{array}$ & $\begin{array}{r}9 \\
20\end{array}$ & $\begin{array}{r}7 \\
24 \\
11\end{array}$ & 33 & $\begin{array}{l}10 \\
34 \\
35\end{array}$ & 12 & $\begin{array}{l}38 \\
44\end{array}$ & 11 & & \\
\hline
\end{tabular}

* Subjects received insulin at 60 minutes and are not included in control data of FFA and glucose tables. 
mal response value (J.S.), representing a statistical probability of difference at the $\mathrm{p}<0.001$ level. The average time to obtain a maximal response as measured from the completion of the infusion was 45 minutes with a range of 20 to 75 minutes. FFA level elevations persisted for the duration of each experiment.

A significant rise in plasma glucose levels also occurred in every instance. The maximal rise in glucose was frequently not attained within the duration of these studies but, when reached, rose to an average of $196 \mathrm{mg}$ per $100 \mathrm{ml}$. In all of the studies in which both FFA and glucose were measured, the first significant rise in glucose was well correlated temporally with the first significant rise in FFA level. As in Figure 1, the pattern of response of glucose levels shortly after the infusion was begun was linear and steep. During the period of linear rise of plasma glucose it is possible to make an approximate calculation of the rate at which glucose is being added to the total body water by way of glycogenolytic and gluconeogenetic processes. This is based on the previous finding that during 2-DG infusion glucose utilization is negligible (5) and that any rise in plasma glucose must be primarily due to glucose production by way of glycogenolysis and gluconeogenesis. In the subject depicted in Figure 1, during a half-hour period of nearly linear glucose rise ( $0-30$ minutes after completing the infusion), the plasma glucose concentration changed $32 \mathrm{mg}$ per $100 \mathrm{ml}$. For a calculated average total body water compartment of 60 per cent of body weight, this plasma concentration increase represents the addition of $26.7 \mathrm{~g}$ of glucose per hour. Table I lists the estimated rates of glucose release for the control subjects (mean, $40.2 \mathrm{~g}$ per hour). Any glucose utilization that occurred during these experimental periods and any renal excretory loss of glucose would serve to make the observed values less than the actual glucose production. Comparable calculations for FFA metabolism cannot be made, since the effects of 2-DG on specific reactions affecting FFA utilization and mobilization are not known.

Lactate. Talble I lists the serum lactate levels in five subjects. In all subjects there was a rise which progressed throughout the study.

Effect of insulin on the response to 2-DG infusion. Figure 2 illustrates an experiment in which

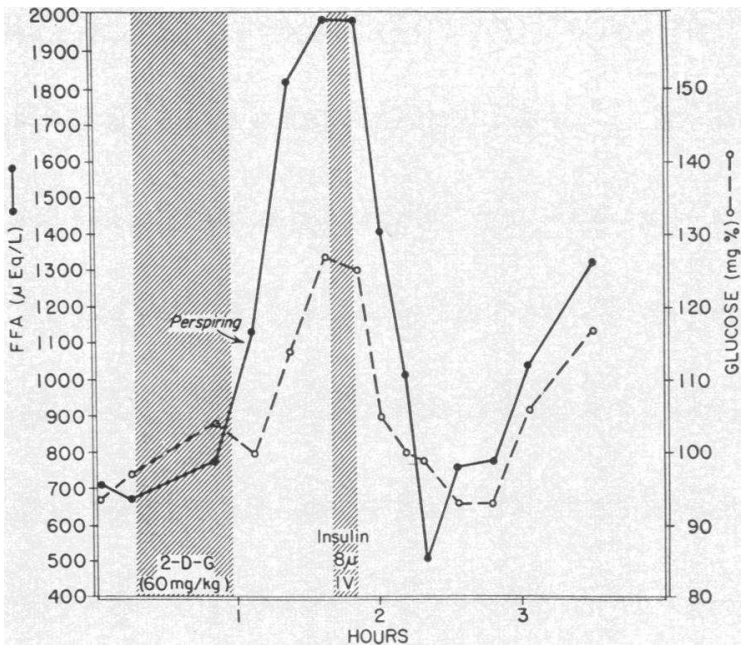

Fig. 2. The effect of HGF insulin ( 0.1 U per kg), INTRAVENOUSLY ADMINISTERED, UPON THE INCREASEI) PLASMA FREE FATTY ACID AND GLUCOSE LENELS FOLLOWING THE INFUSION OF 2-DEOXY-D-GLUCOSE.

a dose of $8 \mathrm{U}$ of HGF-free insulin was administered intravenously over a 3 minute period at a time when the FFA level was expected to be at a maximum. It will be noted that in this experiment, at the time insulin was administered, glucose and FFA levels were on the ascent. Shortly after insulin administration there was a rapid fall in FFA and glucose levels. This fall began to level out approximately 60 minutes after insulin administration. The fall in the FFA level was very sharp, decreasing from 1,993 to $505 \mu \mathrm{Eq}$ per L during a 25 minute period. Despite the rapid reversal in FFA and glucose levels, the subject continued to experience symptoms. At a later point in the study (not recorded in the figure), 25 $\mathrm{g}$ of glucose administered intravenously was accompanied by prompt cessation of the symptoms. A similar study of insulin effect in a second subject revealed the same pattern of response.

Effect of glucose, fructose and lactate on the response to 2-DG. Figure 3 illustrates a series of experiments in Subject G.S. studied on three different occasions. In addition to an unmodified 2-DG infusion study, noted as control, the effects of glucose and fructose on the 2-DG infusion were observed on other days. The peaks of the FFA levels were not the same for all three days but were of a comparable order of magnitude. The major difference between these studies is the rate of fall of the FFA level. After the glucose infu- 
sion, it was considerably increased, control levels of FFA being reached 60 minutes following completion of the 2-DG infusion. In the control study, the FFA level was still markedly elevated 190 minutes following completion of the 2-DG. The reversal effect of glucose on the FFA level gradually diminished as plasma glucose levels returned toward pre-infusion values. At the completion of the study, the FFA level was again elevated. In the study in which fructose was infused, there was a slightly more rapid decline in plasma FFA level as compared with the control day. The plasma glucose level during the fructose experiment was higher than that of the control, a reflection of fructose conversion to glucose which may account for the partial reversibility seen in this experiment.

Five hundred $\mathrm{ml}$ of $1 / 6 \mathrm{M}$ sodium lactate infused simultaneously with 2-DG did not alter the rate of FFA decline. Several other series of experiments using infusions of sodium lactate at varying time intervals after 2-DG administration also seemed to be ineffective in reversing FFA level response to $2-\mathrm{DG}$.

Catechol amine excretion. In four subjects, urinary catechol amine levels were determined be-

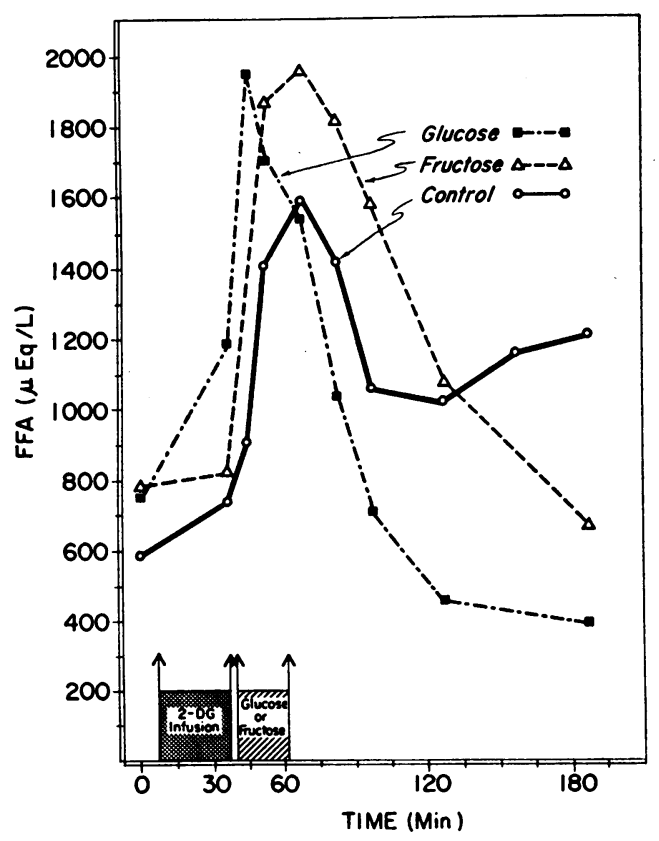

Fig. 3. The efFect of gLucose and FRUCtose Upon THE PLASMA FREE FATTY ACID AND GLUCOSE ELEVATIONS FOLLOWING INFUSION OF 2-DEOXY-D-GLUCOSE.
TABLE II

Catechol amine excretion rates before, during and after intra venous infusion of 2-deoxy-D-glucose

\begin{tabular}{crrr}
\hline \hline Subject & Period* & $\begin{array}{c}\text { Epi- } \\
\text { neph- } \\
\text { rine }\end{array}$ & $\begin{array}{c}\text { Nor- } \\
\text { epi- } \\
\text { neph- } \\
\text { rine }\end{array}$ \\
\hline 7. R.D. & I & $\begin{array}{r}\mu g / h r \\
1.55\end{array}$ & $\mu g / h r$ \\
& II & 31.47 & 6.01 \\
& III & 21.92 & \\
8. R.Me. & I & 4.78 & 34.65 \\
& II & 28.34 & \\
9. J.S. & III & 19.88 & \\
& II & 1.37 & 5.85 \\
& III & 6.79 & 3.35 \\
11. A.N. & II & 2.99 & 18.30 \\
& II & 10.57 & 2.31 \\
& III & 13.03 & 14.12 \\
\hline
\end{tabular}

* Periods: $\mathrm{I}=$ before infusion; $\mathrm{II}=$ during infusion and 1 hour after infusion completed; III $=2$ to 3 hours after infusion completed.

fore, during and after 2-DG infusion (Table II). There was a striking increase in epinephrine excretion in all studies. Because of the proportionality method involved in the bioassay procedure, the norepinephrine levels could not be accurately assessed in the presence of such large amounts of epinephrine. Accordingly, in two experiments norepinephrine levels were not calculated. In the other two experiments the levels tended to fall.

\section{DISCUSSION}

These studies are considered to provide further evidence for the thesis that the status of carbohydrate metabolism is an important determinant of the equilibrium of fat metabolism. Following 2-DG infusion, the sharp rise in FFA levels that occurred in the fasted, resting individual suggests a net increase in fat mobilization as compared with fat synthesis and utilization. The reversal of the 2-DG response by insulin, glucose and fructose would indicate that the effect of 2-DG upon lipid dynamics is most likely a result of the known action of 2-DG as a competitive inhibitor of glucose utilization. The actual mediating mechanisms of this glucose-lipid interrelationship are not specifically delineated by the experiments reported here. White and Engel have studied the effect of 2-DG upon adipose tissue in vitro and have not noted any alteration in FFA release into or uptake from 
the media in such experiments (9). Data on the utilization of FFA by specific tissues samples in vitro in the presence of 2-DG have not been reported. Studies in this laboratory using $\mathrm{C}^{\mathbf{1 4}}$-labeled palmitate do not indicate any effect of $2-\mathrm{DG}$ on the rate of disappearance of infused FFA in human subjects (10).

The FFA level rise observed in these studies might represent a response to 2-DG infusion which is mediated by lipid mobilizing processes present only in the intact subject. The symptoms of drowsiness, hunger and marked sweating suggest the response recognized as the one attending hypoglycemia. In the presence of $2-D G$, although the measured plasma level of glucose is high, if cellular utilization of glucose cannot occur the organism can be considered to be functionally hypoglycemic. The relative unavailability of glucose to the central nervous system might then initiate the usual response of the organism to hypoglycemia which characteristically includes adrenal medullary secretion. Epinephrine and norepinephrine are both known to raise plasma FFA levels and to have an in vitro lipolytic property $(1,11$, 12). In the studies reported here, the marked increases in urinary epinephrine excretion and the immediate rise in plasma glucose level that follows the 2-DG infusion would be consistent with the hypothesis that the FFA level rises are mediated by a mechanism involving the adrenal medulla.

Significant rises in plasma glucose invariably follow 2-DG infusion and sometimes persist for 6 to 8 hours. In this experimental situation, when glucose utilization is markedly blocked, the amount of net glucose added to the body water may be calculated. This net increment of glucose most likely represents both glucose release by way of glycogenolysis and glucose elaboration by the process of gluconeogenesis. Values of 9 to $90 \mathrm{~g}$ of glucose per hour were obtained by such calculations. The magnitude of these figures approximates, and in some instances exceeds, those estimates of Bearn, Billing and Sherlock $(13,14)$ and of Werk and associates (15).

The symptoms experienced as a result of the 2-DG infusion were reversed by the administration of glucose but not by insulin, although the FFA rise was equally well reversed by both procedures. The protective effect of glucose on 2-DG toxicity, as well as the failure of insulin to protect against 2-DG toxicity, has also been observed in mice (16). The lack of reversal by insulin may be due to the reduction of serum glucose subsequent to insulin injection. In this experimental situation the FFA level is being modified by an insulin-sensitive tissue (adipose), but the 2-DG effects on the central nervous system are occurring in an insulin-insensitive tissue (the brain).

Finally, with the thesis in mind that the key role of glucose metabolism in governing FFA levels might be concerned with glucose serving as a source of glycerol for the esterification of free fatty acids, lactate infusions were given so as to provide an alternate source of three carbon compounds. In our study of a series of lactate infusions at varying dosage levels and at different times with relation to $2-\mathrm{DG}$ administration, we were unable to demonstrate any reversal of the plasma FFA response to 2-DG. However, Mueller who independently found that 2-DG infusions in dogs caused consistent plasma FFA rises, noted that the administration of lactate reversed the FFA rise (17). Our failure to demonstrate a similar lactate reversal effect in man may be due to the different dosages employed, or else to the species difference in the handling of lactate and the degree to which exogenous lactate is available to esterify fatty acids.

\section{SUM M ARY}

1. 2-Deoxy-D-glucose (2-DG), a competitive inhibitor of glucose metabolism, was administered intravenously to a series of fasting, rested subjects.

2. Plasma levels of free fatty acid (FFA), glucose and lactate increased markedly following the infusion of 2-DG.

3. Insulin, glucose and fructose reversed the rise in plasma FFA but did not alter plasma lactate levels. Lactate infusion did not alter the FFA or glucose response to 2-DG. Insulin also reversed the glucose rise following 2-DG but not the clinical side effects.

4. Marked increases in urinary excretion of epinephrine accompany and follow the infusion of 2-DG and suggest that the mechanism mediating the plasma FFA response may involve the adrenal medulla.

5. 2-DG infusion in the fasting individual may provide a technique for making a quantitative es- 
timate of the magnitude of net glucose release in man.

\section{ACKNUWLEDGMENTS}

The authors would like to acknowledge with gratitude the technical assistance of Helen Hilderman, Nancy Johnson, Corinna Thomas and Gitta Jackson.

\section{REFERENCES}

1. Dole, V. P. The relation between non-esterified fatty acids in plasma and the metabolism of glucose. J. clin. Invest. 1956, 35, 150.

2. Bierman, E. L., Dole, V. P., and Roberts, T. N. An abnormality of non-esterified fatty acid metabolism in diabetes mellitus. Diabetes 1957, 6, 475.

3. Kipnis, D. M., and Cori, C. F. Studies of tissue permeability. V. The penetration and phosphorylation of 2-deoxyglucose in the rat diaphragm. J. biol. Chem. 1959, 234, 171.

4. Nelson, N. A photometric adaptation of the Somogyi method for the determination of glucose. J. biol. Chem. 1944, 153, 375.

5. Landau, B. R., Laszlo, J., Stengle, J., and Burk, D. Certain metabolic and pharmacologic effects in cancer patients given infusions of 2-deoxy-D-glucose. J. nat. Cancer Inst. 1958, 21, 485.

6. Trout, D. L., Estes, E. H., Jr., and Friedberg, S. J. Titration of free fatty acids of plasma: A study of current methods and a new modification. J. Lip. Res. 1960, 1, 199.

7. Barker, S. B., and Summerson, W. H. The colorimetric determination of lactic acid in biological material. J. biol. Chem. 1941, 138, 535.
8. von Euler, U. S. The distribution of sympathin $\mathrm{N}$ and sympathin $A$ in spleen and splenic nerves of cattle. Acta physiol. scand. 1949, 19, 207.

9. White, J. E., and Engel, F. L. Personal communication.

10. Friedberg, S. J., Laszlo, J., and Klein, R. F. Unpublished observations.

11. Gordon, R. S., Jr., and Cherkes, A. Production of unesterified fatty acids from isolated rat adipose tissue incubated in iitro. Proc. Soc. exp. Biol. (N. Y.) 1958, 97, 150.

12. White, J. E., and Engel, F. L. The lipolytic action of epinephrine and norepinephrine on rat adipose tissue in vitro. Proc. Soc. exp. Biol. (N. Y.) 1958, 99, 375.

13. Bearn, A. G., Billing, B. H., and Sherlock, S. The response of the liver to insulin in normal subjects and in diabetes mellitus: Hepatic vein catheterisation studies. Clin. Sci. 1952, 11, 151.

14. Bearn, A. G., Billing, B. H., and Sherlock, S. The effect of adrenaline and noradrenaline on hepatic blood flow and splanchnic carbohydrate metabolism in man. J. Physiol. (Lond.) 1951, 115, 430.

15. Werk, E. E., Jr., McPherson, H. T., Hamrick, L. W., Jr., Myers, J. D., and Engel, F. L. Studies on ketone metabolism in man. I. A method for the quantitative estimation of splanchnic ketone production. J. clin. Invest. 1955, 34, 1256.

16. Laszlo, J., Humphreys, S. R., and Goldin, A. Effects of glucose analogues (2-deoxy-D-glucose, 2-deoxyD-galactose) on experimental tumors. J. nat. Cancer Inst. 1960, 24, 267.

17. Mueller, P. S. Personal communication. 